\title{
Kajian Suseptibilitas Magnetik Bergantung Frekuensi terhadap Pasir Besi Kabupaten Takalar
}

\section{Study of Frequency-Dependent Magnetic Susceptibility to the Iron Sand in Takalar Regency}

\author{
Vistarani Arini Tiwow ${ }^{1 \text { * }}$, Meytij Jeanne Rampe ${ }^{2)}$, dan Muhammad Arsyad ${ }^{3)}$ \\ 1,3) KBK Fisika Bumi, Jurusan Fisika, Universitas Negeri Makassar \\ 2) Program Studi Kimia, Jurusan Kimia, Universitas Negeri Manado
}

Received $4^{\text {th }}$ July 2018/Accepted 20 ${ }^{\text {th }}$ September 2018

\begin{abstract}
ABSTRAK
Telah dilakukan penelitian mengenai kajian suseptibilitas magnetik bergantung frekuensi terhadap pasi besi Kabupaten Takalar. Tujuan penelitian ini adalah mengidentifikasi mineral magnetik yang dominan berdasarkan data suseptibilitas magnetik dan menganalisis sumber mineral magnetik berdasarkan suseptibilitas magnetik bergantung frekuensi. Metode yang digunakan adalah metode magnetik batuan khususnya parameter suseptibilitas magnetik. Pengukuran dilakukan menggunakan alat Bartington MS2 Susceptibility Meter dilengkapi sensor MS2B yang bekerja pada frekuensi rendah $(470 \mathrm{~Hz})$ dan frekuensi tinggi (4700 $\mathrm{Hz})$. Hasil penelitian mengindikasikan pasir besi mengandung mineral ferrimagnetik yaitu magnetite. Nilai suseptibilitas magnetik pada frekuensi rendah dan frekuensi tinggi identik serta persentase suseptibilitas magnetik bergantung frekuensi diperoleh kurang dari $2 \%$ yang mengindikasikan pasir besi memiliki bulir magnetik multi domain (MD). Korelasi positif antara suseptibilitas magnetik pada frekuensi rendah dengan bergantung frekuensi mengindikasikan sumber mineral magnetik yang dominan berasal proses pedogenik yaitu pelapukan batuan gunung api.
\end{abstract}

Kata kunci: suseptibilitas magnetik, suseptibilitas magnetik bergantung frekuensi, ferrimagnetik, bulir multi domain, pedogenik.

\begin{abstract}
Research on the study of frequency-dependent magnetic susceptibility to the iron sand in Takalar Regency has been conducted. The purpose of this study was to identify dominant magnetic minerals based on magnetic susceptibility data and analyze magnetic mineral sources based on frequency-dependent magnetic susceptibility. The method used was the magnetic rock method, especially the parameters of magnetic susceptibility. Measurements were made using a Bartington MS2 Susceptibility Meter device equipped with an MS2B sensor that works at low frequency $(470 \mathrm{~Hz})$ and high frequency (4700
\end{abstract}

*Korespondensi:

email:vistatiwow@unm.ac.id 
$\mathrm{Hz}$ ). The results indicate that iron sand contains ferrimagnetic minerals, namely magnetite. The value of magnetic susceptibility at low frequency and high frequency were identical and the percentage of frequency-dependent magnetic susceptibility was less than $2 \%$ which indicates that iron sand has multidomain magnetic grains (MD). The positive correlation between magnetic susceptibility at low frequency and frequency dependent indicates the dominant source of magnetic minerals derived from pedogenic processes, namely the weathering of volcanic rocks.

Keywords: magnetic susceptibility, frequency-dependent magnetic susceptibility, ferromagnetic, multi domain grains, pedogenic.

\section{PENDAHULUAN}

Sulawesi Selatan merupakan salah satu provinsi di Indonesia yang memiliki kekayaan sumber daya mineral, misalnya pasir besi. Potensi pasir besi di Sulawesi Selatan khususnya di Kabupaten Takalar cukup besar. Namun, belum dimanfaatkan (belum ditambang) disebabkan oleh informasi yang belum memadai. Pasir besi terbentuk karena adanya aktivitas letusan gunung berapi atau intrusi magma dan sungai yang melintas di pantai. Lokasi gunung berapi di Sulawesi Selatan seperti Gunung Lompobattang yang tidak aktif lagi, serta banyak arus sungai menuju barat dan selatan, sehingga dihasilkan pasir besi dari pelapukan batuan yang diangkut dan terakumulasi di pantai. Sumber pasir besi adalah batuan yang bersifat intermediate terhadap base dan andesitik terhadap basaltik.

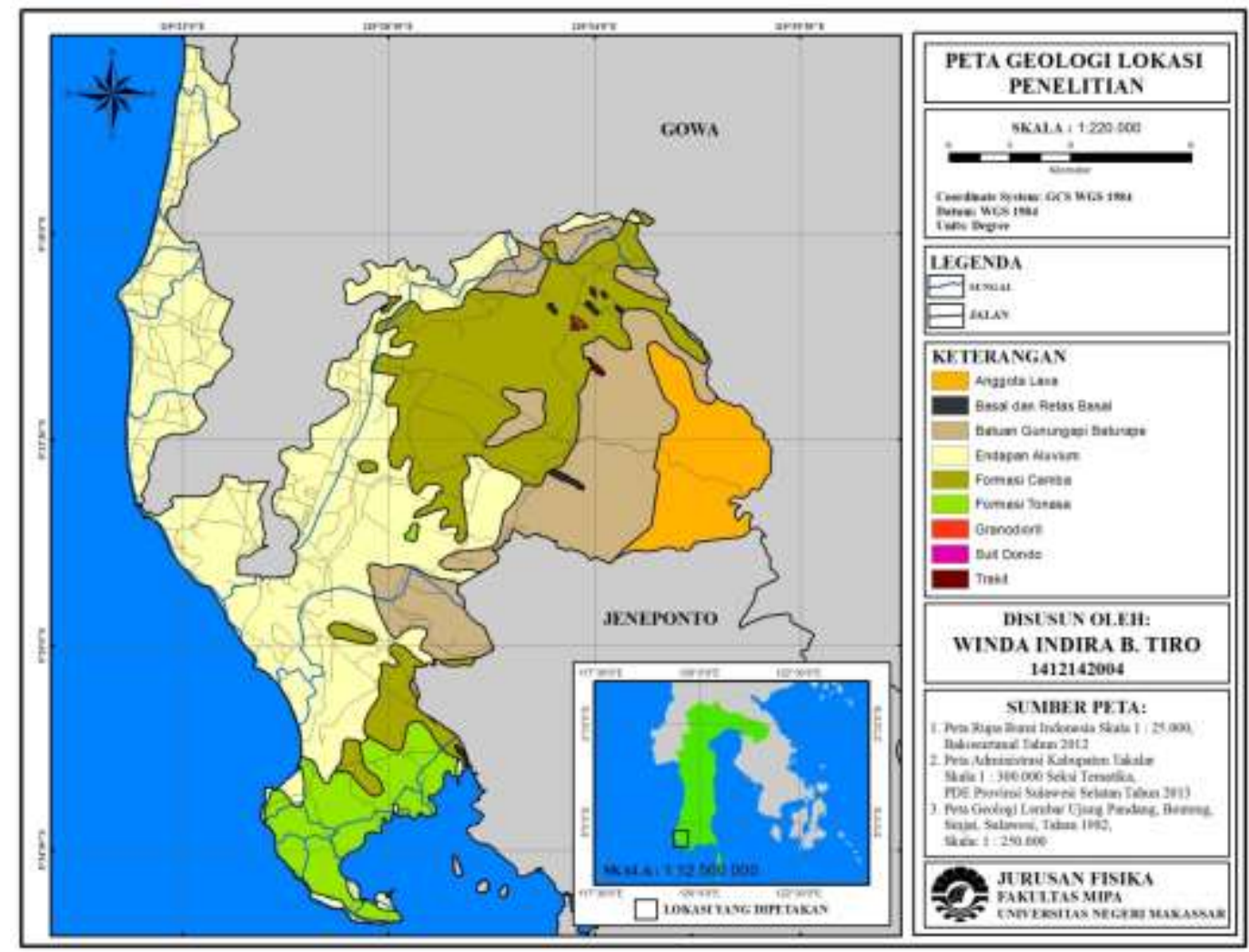

Gambar 1. Peta Geologi Kabupaten Takalar 
Struktur geologi Kabupaten Takalar dipengaruhi oleh formasi camba, terobosan, gunung api cindako, formasi tonasa dan endapan aluvium. Masing-masing formasi batuan tersebut memiliki karakteristik yang membentuk struktur tanah dan batuan, antara lain formasi terobosan, terbentuk atas batuan basal, formasi Camba terbentuk atas sendimen laut berselingan, formasi Tonasa terbentuk atas batuan gamping, formasi gunung api-Cindako, terbentuk atas batuan lava-breksi-tufa-konglomerat dan terutama lava, dan endapan alivium dan pantai, terbentuk atas kerikil, pasir, lempung, dan lumpur (gambar 1).

Bahan alam pasir besi kaya akan mineral yang mengandung besi. Pasir besi mengandung mineral-mineral magnetik seperti magnetit $\left(\mathrm{Fe}_{3} \mathrm{O}_{4}\right)$, hematit $\left(\alpha-\mathrm{Fe}_{2} \mathrm{O}_{3}\right)$, maghemit $\left(\gamma-\mathrm{Fe}_{2} \mathrm{O}_{3}\right)$, dan ilmenit $\left(\mathrm{FeTiO}_{3}\right)$ (Findorak, et al., 2014; Nugraha, et al., 2016; Bassez, 2017). Pada pasir juga terdapat unsur pengotor seperti silikon (Si), kalsium (Ca), magnesium $(\mathrm{Mg})$, aluminium $(\mathrm{Al})$, chromium $(\mathrm{Cr})$, mangan $(\mathrm{Mn})$, dan lain sebagainya. Mineral magnetik dapat digunakan sebagai bahan dasar pembuatan toner (Ataeefard, et al., 2014), pigmen (Mufti, et al., 2014), dan industri logam lainnya.

Kualitas endapan pasir besi dapat dilakukan dengan metode magnetik batuan (rock magnetism) khususnya parameter suseptibilitas magnetik. Metode ini relatif sederhana, cepat dalam mendapatkan hasil, tidak merusak sampel, dan terjangkau (Bijaksana dkk, 2013). Beberapa kajian tentang karakteristik pasir besi dengan memanfaatkan metode magnetik sebelumnya pernah dilakukan juga oleh Tamuntuan dkk (2010) menggunakan sampel dari danau di Jawa Tmur dan Sulawesi Selatan, Jahidin (2012) menggunakan sampel dari Desa Laea, Sulawesi Tenggara, Tanauma dan Ferdy (2011) serta Tamuntuan dkk (2017) menggunakan sampel dari pantai timur dan barat Sulawesi Utara.

Pengukuran suseptibilitas magnetik dapat dilakukan pada dua frekuensi yaitu frekuensi rendah $(470 \mathrm{~Hz})$ dan frekuensi tinggi $(4700 \mathrm{~Hz})$. Perbedaan suseptibilitas magnetik pada frekuensi rendah dan frekuensi tinggi disebut suseptibilitas magnetik bergantung frekuensi yang dapat digunakan melacak sumber mineral magnetik yang dominan (Kirana, dkk., 2014). Sumber mineral magnetik dapat berasal dari aktivitas manusia (antropogenik) dan alami (pedogenik). Beberapa kasus seperti polusi tanah (Dlouha, et, al., 2013; Aydin dan Aykol, 2015), polusi sungai (Nurbaiti, 2011; Bilinski et al., 2014), guano pada gua (Sari, dkk., 2013; Rahmadhani, dkk., 2013), dan sebagainya.

Penelitian ini bertujuan mengidentifikasi mineral magnetik yang dominan pada pasir besi berdasarkan data suseptibilitas magnetik serta menganalisis suseptibilitas magnetik bergantung frekuensi untuk mengetahui sumber mineral yang dominan.

\section{METODE PENELITIAN}

Pasir besi diambil di Pantai Sampulungan Kabupaten Takalar pada 30 titik. Masingmasing titik pasir besi diambil pada kedalaman $1 \mathrm{~m}$. Pasir besi dicuci, dikeringkan pada suhu kamar, diseparasi menggunakan magnet batang (Sunaryono, et al., 2015; Setiadi, et al., 2016), diayak menggunakan ayakan 100 mesh, dan ditimbang sebesar 10 g. Selanjutnya, pengukuran suseptibilitas magnetik dilakukan pada sampel menggunakan Bartington MS2 Susceptibility Meter (Bartington Instrument Ltd., Oxford, United Kingdom) dilengkapi sensor MS2B yang bekerja pada dua frekuensi (470 Hz and $4700 \mathrm{~Hz}$ ). Data suseptibilitas 
magnetik pada frekuensi rendah menggunakan data sekunder. Pengukuran ini untuk memperoleh suseptibilitas magnetik bergantung frekuensi dengan menggunakan persamaan (Tamuntuan, et. al., 2010):

$$
\chi_{F D}\left(m^{3} / k g\right)=\chi_{L F}-\chi_{H F} \text { dan } \chi_{F D}(\%)=\frac{\chi_{L F}-\chi_{H F}}{\chi_{L F}} 100
$$

Sampel pasir besi juga dikarakterisasi menggunakan X-Ray Fluorescence (XRF) untuk mengetahui komposisi unsur.

\section{HASIL DAN PEMBAHASAN}

Tabel 1. Nilai suseptibilitas magnetik sampel pasir besi Kabupaten Takalar

\begin{tabular}{|c|c|c|c|c|}
\hline $\begin{array}{l}\text { Kode } \\
\text { Sampel }\end{array}$ & $\begin{array}{c}\chi_{L F} \\
\left(\times 10^{-8} \mathrm{~m}^{3} / \mathrm{kg}\right)\end{array}$ & $\begin{array}{c}\chi_{H F} \\
\left(\times 10^{-8} \mathrm{~m}^{3} / \mathrm{kg}\right)\end{array}$ & $\begin{array}{c}\chi_{\text {FD }} \\
\left(\times 10^{-8} \mathrm{~m}^{3} / \mathrm{kg}\right)\end{array}$ & $\begin{array}{l}\chi_{\mathrm{FD}} \\
(\%)\end{array}$ \\
\hline WT1 & 62559,60 & 62157,29 & 402,31 & 0,64 \\
\hline WT2 & 55977,69 & 55652,93 & 324,77 & 0,58 \\
\hline WT3 & 66121,34 & 66038,17 & 83,17 & 0,13 \\
\hline WT4 & 63152,22 & 63101,84 & 50,38 & 0,08 \\
\hline WT5 & 63379,88 & 62994,99 & 384,89 & 0,61 \\
\hline WT6 & 71383,37 & 71295,08 & 88,29 & 0,12 \\
\hline WT7 & 62490,19 & 62369,73 & 120,47 & 0,19 \\
\hline WT8 & 61069,57 & 60983,91 & 85,66 & 0,14 \\
\hline WT9 & 33932,63 & 33820,99 & 111,64 & 0,33 \\
\hline WT10 & 54042,46 & 53978,01 & 64,46 & 0,12 \\
\hline WT11 & 63199,28 & 62981,77 & 217,51 & 0,34 \\
\hline WT12 & 64321,71 & 64031,53 & 290,18 & 0,45 \\
\hline WT13 & 64506,11 & 64187,84 & 318,27 & 0,49 \\
\hline WT14 & 67251,12 & 67039,03 & 212,09 & 0,32 \\
\hline WT15 & 71829,96 & 71702,67 & 127,29 & 0,18 \\
\hline WT16 & 71008,14 & 70816,19 & 191,95 & 0,27 \\
\hline WT17 & 65875,86 & 65730,44 & 145,43 & 0,22 \\
\hline WT18 & 68121,15 & 67837,05 & 284,10 & 0,42 \\
\hline WT19 & 58476,30 & 58378,24 & 98,06 & 0,17 \\
\hline WT20 & 65734,56 & 65346,73 & 387,83 & 0,59 \\
\hline WT21 & 61058,70 & 60945,43 & 113,27 & 0,19 \\
\hline WT22 & 63240,30 & 62980,87 & 259,43 & 0,41 \\
\hline WT23 & 57192,61 & 57091,63 & 100,98 & 0,18 \\
\hline WT24 & 56566,93 & 56320,97 & 245,96 & 0,43 \\
\hline WT25 & 67579,90 & 67348,50 & 231,40 & 0,34 \\
\hline WT26 & 70943,02 & 70545,07 & 397,95 & 0,56 \\
\hline WT27 & 43385,55 & 43281,73 & 103,82 & 0,24 \\
\hline WT28 & 63316,22 & 63140,99 & 175,23 & 0,28 \\
\hline WT29 & 68369,74 & 68129,41 & 240,33 & 0,35 \\
\hline WT30 & 67240,32 & 66798,71 & 441,60 & 0,66 \\
\hline
\end{tabular}


Hasil pengukuran suseptibilitas magnetik pada frekuensi rendah, frekuensi tinggi, bergantung frekuensi ditampilkan pada tabel 1. Nilai suseptibilitas magnetik pada frekuensi rendah berkisar $33932,63 \times 10^{-8} \mathrm{~m}^{3} / \mathrm{kg}$ hingga $71829,96 \times 10^{-8} \mathrm{~m}^{3} / \mathrm{kg}$. Berdasarkan klasifikasi mineral menurut Dearing (1999) menunjukkan bahwa sampel pasir besi Kabupaten Takalar mengandung mineral magnetite dan bersifat ferrimagnetik. Ini sesuai dengan penelitian sebelumnya yang telah dilakukan Tiwow, et. al. (2018) dan Fahlepy, et. al. (2018) bahwa pasir besi Kabupaten Takalar mengandung mineral magnetite.

Tingginya suseptibilitas magnetik pada frekuensi rendah mengindikasikan tinggi pula kandungan mineral magnetik pada sampel pasir ini. Hasil ini sesuai dengan hasil karakterisasi XRF (tabel 2). Tampak bahwa unsur besi (Fe) mendominasi dan unsur-unsur pengotor seperti titanium (Ti), chromium (Cr), mangan (Mn), dan vanadium (V).

Tabel 2. Komposisi unsur sampel pasir besi Kabupaten Takalar

\begin{tabular}{cccccc}
\hline \multirow{2}{*}{ Kode } & \multicolumn{5}{c}{ Komposisi unsur } \\
\cline { 2 - 6 } sampel & Fe (\%) & Ti $(\boldsymbol{\%})$ & Cr $(\boldsymbol{\%})$ & V $(\boldsymbol{\%})$ & $\begin{array}{c}\text { Mn } \\
\text { (\%) }\end{array}$ \\
\hline WT1 & 42.92 & 5.22 & 0.077 & 0.333 & 0.395 \\
WT2 & 41.52 & 5.11 & 0.068 & 0.291 & 0.387 \\
WT3 & 47.90 & 5.64 & 0.094 & 0.343 & 0.415 \\
WT4 & 44.09 & 5.29 & 0.074 & 0.312 & 0.404 \\
WT5 & 46.11 & 5.41 & 0.083 & 0.329 & 0.394 \\
WT6 & 47.49 & 5.50 & 0.086 & 0.338 & 0.429 \\
WT7 & 42.57 & 5.19 & 0.078 & 0.310 & 0.391 \\
WT8 & 41.05 & 4.99 & 0.081 & 0.308 & 0.360 \\
WT9 & 20.19 & 2.82 & 0.045 & 0.158 & 0.238 \\
WT10 & 40.82 & 4.99 & 0.062 & 0.310 & 0.372 \\
WT11 & 41.94 & 5.16 & 0.068 & 0.318 & 0.389 \\
WT12 & 44.13 & 5.22 & 0.077 & 0.324 & 0.418 \\
WT13 & 48.39 & 5.58 & 0.085 & 0.332 & 0.397 \\
WT14 & 47.84 & 5.53 & 0.094 & 0.335 & 0.422 \\
WT15 & 50.58 & 5.68 & 0.096 & 0.352 & 0.433 \\
WT16 & 47.99 & 5.59 & 0.109 & 0.350 & 0.411 \\
WT17 & 43.81 & 5.21 & 0.077 & 0.333 & 0.403 \\
WT18 & 48.76 & 5.68 & 0.088 & 0.343 & 0.411 \\
WT19 & 41.97 & 5.05 & 0.079 & 0.312 & 0.377 \\
WT20 & 46.62 & 5.56 & 0.086 & 0.247 & 0.384 \\
WT21 & 42.26 & 5.26 & 0.074 & 0.313 & 0.401 \\
WT22 & 46.56 & 5.43 & 0.096 & 0.323 & 0.406 \\
WT23 & 41.02 & 5.02 & 0.083 & 0.317 & 0.379 \\
WT24 & 41.47 & 5.03 & 0.073 & 0.299 & 0.367 \\
WT25 & 48.05 & 5.55 & 0.096 & 0.352 & 0.401 \\
WT26 & 46.92 & 5.43 & 0.083 & 0.333 & 0.388 \\
WT27 & 35.62 & 4.66 & 0.075 & 0.285 & 0.347 \\
WT28 & 46.97 & 5.46 & 0.079 & 0.323 & 0.400 \\
WT29 & 49.11 & 5.70 & 0.086 & 0.343 & 0.413 \\
WT30 & 48.43 & 5.57 & 0.089 & 0.339 & 0.432 \\
\hline & & & & &
\end{tabular}


Tabel 1 juga memperlihatkan bahwa nilai suseptibilitas magnetik pada frekuensi rendah lebih tinggi daripada suseptibilitas magnetik pada frekuensi tinggi. Pengukuran yang dilakukan pada dua frekuensi ini diterapkan pada medan magnet konstan, umumnya digunakan untuk mendeteksi keberadaan mineral ultrafine-ferrimagnetik (superparamagnetik fraksinya kurang dari $0,03 \mu \mathrm{m}$ ) yang terjadi sebagai kristal dan sampai batas tertentu domain tunggal (kira-kira fraksi lebih besar dari 0,03 sampai kurang dari $0,06 \mu \mathrm{m})$.

Pengukuran frekuensi yang lebih tinggi tidak memungkinkan butir superparamagnetik bereaksi dengan medan magnet yang digunakan, karena perubahan lebih cepat daripada waktu relaksasi yang diperlukan untuk bulir superparamagnetik. Akibatnya, dalam frekuensi yang lebih tinggi, nilai suseptibilitas magnetik yang lebih rendah ditemui. Perbedaannya digunakan untuk memperkirakan partikel ferrimagnetik superparamagnetik. Ketika mineral superparamagnetik hadir dalam sampel pasir besi, nilai-nilai suseptibilitas magnetik pada frekuensi tinggi sedikit lebih rendah dari nilai suseptibilitas magnetik pada frekuensi rendah. Jika tidak ada mineral superparamagnetik (SP), kedua pengukuran itu identik.

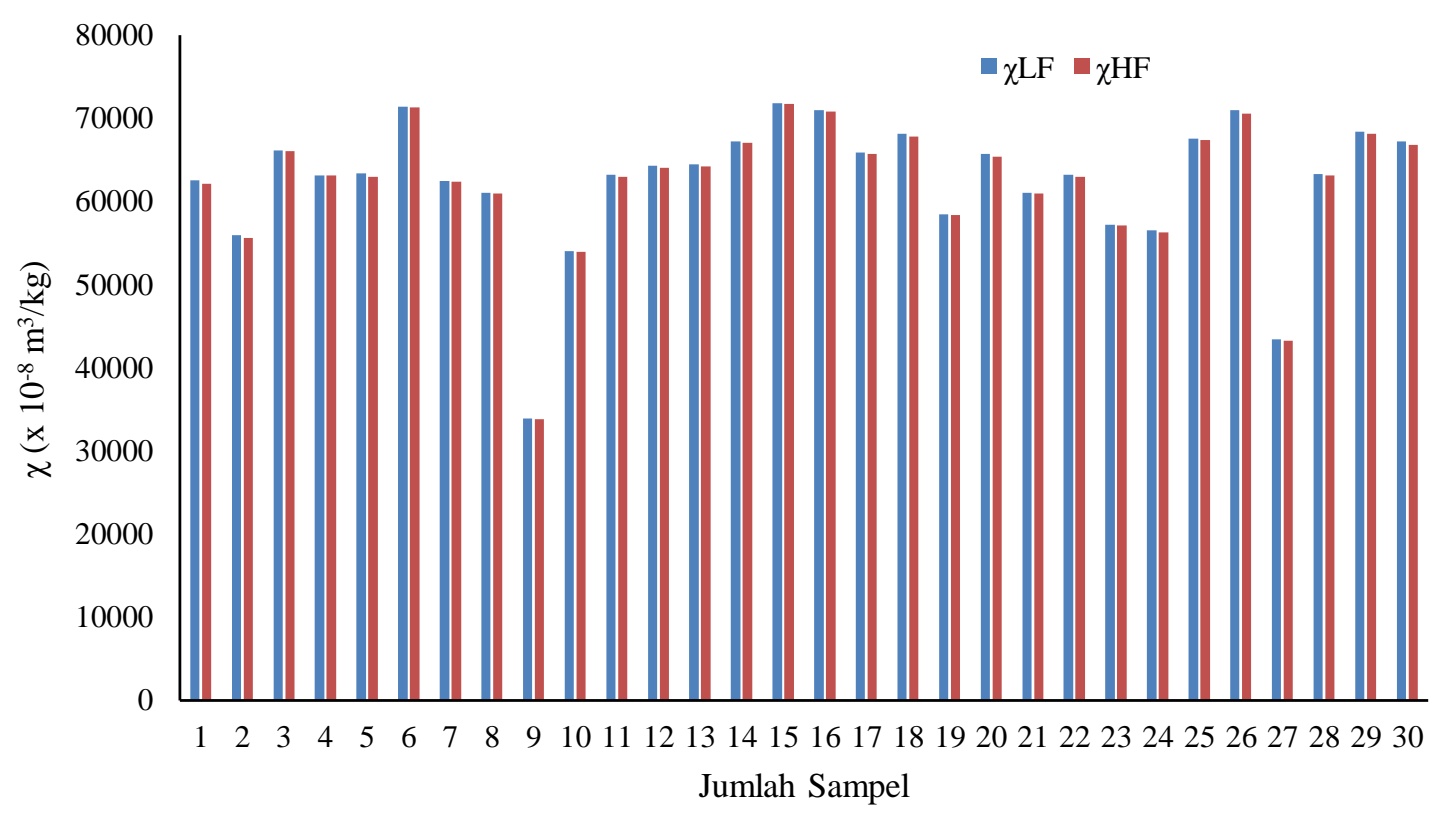

Gambar 2. Nilai suseptibilitas magnetik pada frekuensi rendah $\left(\chi_{\mathrm{LF}}\right)$ dan frekuensi tinggi $\left(\chi_{\mathrm{HF}}\right)$ sampel pasir besi Kabupaten Takalar 


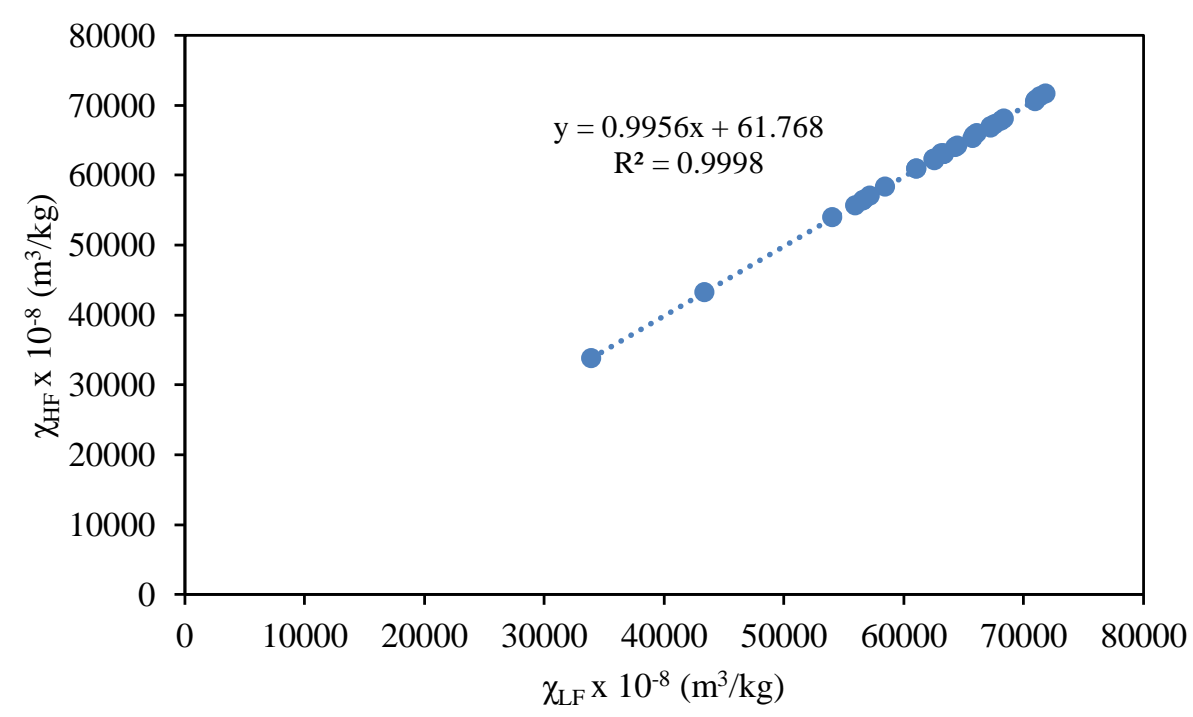

Gambar 3. Hubungan antara suseptibilitas magnetik pada frekuensi rendah $\left(\chi_{\mathrm{LF}}\right)$ dan frekuensi tinggi $\left(\chi_{\mathrm{HF}}\right)$ sampel pasir besi Kabupaten Takalar

Pada penelitian ini, hasil pengukuran menunjukkan bahwa nilai suseptibilitas magnetik pada frekuensi tinggi dan frekuensi rendah terdapat perbedaan tidak signifikan, sehingga bisa dikatakan identik (gambar 2). Artinya, pasir besi hampir tidak mengandung mineral superparamagnetik. Hal ini terlihat pada nilai suseptibilitas magnetik bergantung frekuensi berkisar 50,38-441,6 x $10^{-8} \mathrm{~m}^{3} / \mathrm{kg}$. Berdasarkan ungkapan Dearing (1999) bahwa nilai suseptibilitas bergantung frekuensi untuk bulir simple single domain (SSD) $\sim 30 \times 10^{-6} \mathrm{~m}^{3} / \mathrm{kg}$ dan untuk bulir superparamagnetik (SP) $75-160 \times 10^{-6} \mathrm{~m}^{3} / \mathrm{kg}$. Hubungan antara suseptibilitas pada frekuensi rendah dan frekuensi tinggi ditampilkan pada gambar 3 menunjukkan hubungan yang linier dengan tingkat korelasi yang sangat signifikan.

Gambar 4 menunjukkan perbandingan nilai suseptibilitas magnetik bergantung frekuensi $\left(\chi_{\mathrm{FD}}\right)$ dengan frekuensi rendah $\left(\chi_{\mathrm{LF}}\right)$. Peningkatan suseptibilitas magnetik berkaitan dengan peningkatan suseptibilitas magnetik bergantung frekuensi (Dearing, 1996). Dalam penelitian ini memperlihatkan bahwa korelasi linear yang cukup kecil yaitu 0,089. Menurut Kanu, et. al. (2013) mengatakan bahwa korelasi linear mengindikasikan bahwa peningkatan nilai suseptibilitas magnetik lebih dikontrol oleh kontribusi dari fraksi magnetik yang halus. 


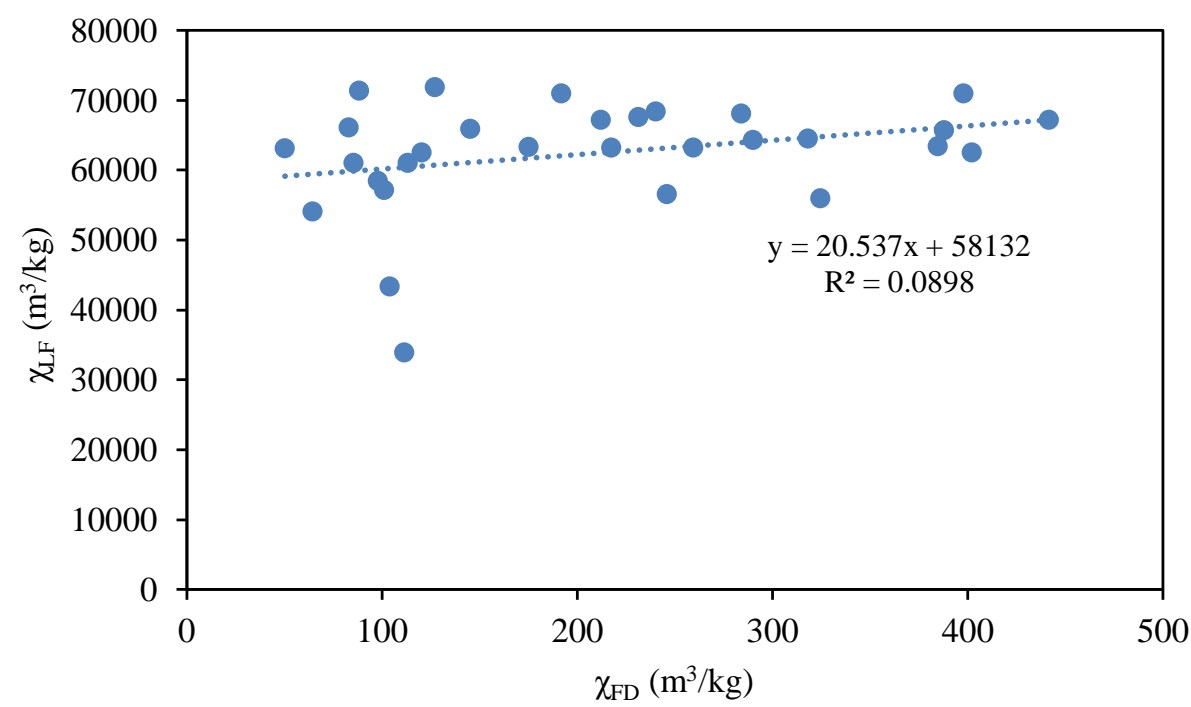

Gambar 4. Regresi linear antara suseptibilitas magnetik bergantung frekuensi $\left(\chi_{\mathrm{FD}}\right)$ dan frekuensi rendah $\left(\chi_{\mathrm{LF}}\right)$ sampel pasir besi Kabupaten Takalar

Persentase suseptibilitas magnetik bergantung frekuensi digunakan untuk memperkirakan konsentrasi total bulir superparamagnetik. Berdasarkan tabel 1 memperlihatkan bahwa persentase suseptibilitas magnetik bergantung frekuensi kurang dari $2 \%$. Menurut Dearing (1999), nilai persentase tersebut termasuk dalam kelompok persentase yang rendah dan mengindikasikan bahwa hampir tidak ada bulir superparamagnetik pada sampel pasir besi. Selain itu juga, tabel 1 dan gambar 2 yang memperlihatkan nilai suseptibilitas magnetik pada frekuensi rendah dan frekuensi tinggi yang identic mengindikasikan bulir yang terkandung pada sampel pasir besi adalah multi domain (MD). Hasil ini sesuai dengan teori yang menyatakan bahwa bulir magnetik multi domain (MD) adalah frekuensi independen karena menunjukkan nilai suseptibilitas magnetik yang sama pada frekuensi rendah dan tinggi (Kanu, et. al., 2013).

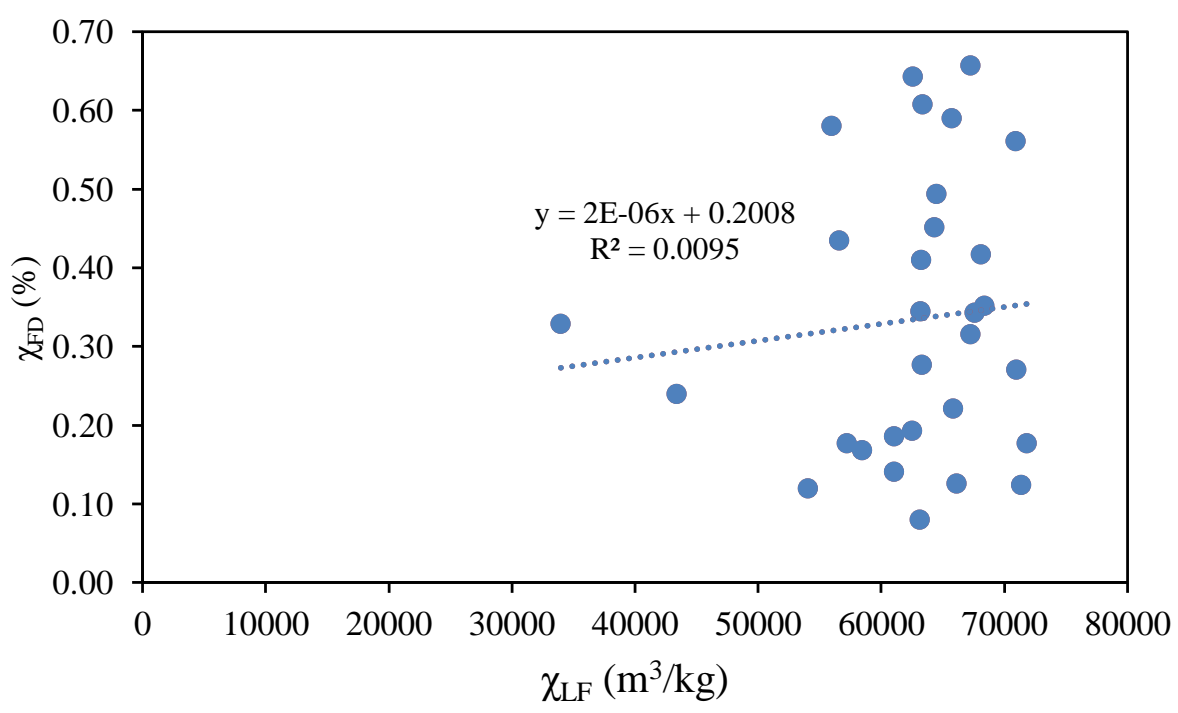

Gambar 5. Korelasi suseptibilitas magnetik pada frekuensi rendah $\left(\chi_{\mathrm{LF}}\right)$ dengan suseptibilitas magnetik bergantung frekuensi $\left(\chi_{\mathrm{FD}}\right)$ sampel pasir besi Kabupaten Takalar 
Gambar 5 menunjukkan korelasi suseptibilitas magnetik pada frekuensi rendah dengan persentase suseptibilitas magnetik bergantung frekuensi. Tampak bahwa korelasinya positif. Artinya bahwa peningkatan suseptibilitas magnetik disebabkan oleh adanya bulir multi domain (MD) yang bersifat ferrimagnetik. Suseptibilitas magnetik dari sampel pasir besi berasal dari batuan gunung api biasanya meningkat dengan peningkatan pada suseptibilitas magnetik bergantung frekuensi. Berdasarkan peta geologi daerah penelitian (gambar 1) menunjukkan bahwa jenis batuan Kabupaten Takalar adalah batuan vulkanik. Batuan vulkanik ini berasal dari gunung api Baturape-Cindako yang terdiri dari lava dan batuan piroklastik yang bersilangan dengan tufa dan batu pasir yang kaya akan mineral magnetite (Zulkifli, dkk., 2002).

\section{KESIMPULAN}

Nilai suseptibilitas magnetik pada frekuensi rendah untuk sampel pasir besi Kabupaten Takalar berkisar 33932,63-71829,96 × 10-8 m3/kg yang mengindikasikan mengandung mineral magnetite yang bersifat ferrimagnetik. Nilai suseptibilitas magnetik pada frekuensi tinggi dan frekuensi rendah identik serta suseptibilitas magnetik bergantung frekuensi kurang dari $2 \%$ yang mengindikasikan pada sampel pasir besi mengandung bulir multi domain (MD). Selain itu, korelasi positif antara suseptibilitas magnetik pada frekuensi rendah dan persentase suseptibilitas magnetik bergantung frekuensi yang mengindikasikan sumber mineral ferrimagnetik pada endapan pasir besi Kabupaten Takalar berasal dari proses alami (pedogenik) yaitu pelapukan batuan gunung api.

\section{DAFTAR PUSTAKA}

Ataeefard, M., Ghasemi, E., and Ebadi, M. 2014. Effect of Micro- and Nanomagnetite on Printing Toner Properties. The Scientific World Journal, 2014, 706367.

Bassez, M. P. 2017. Ferromagnesian Silicate and Ferrosulfide Rocks as a Source of Magnetite and Hydrogen. Procedia Earth and Planetary Science, 17, 492 - 495.

Bijaksana, S., Huliselan, E., Safiuddin, L.O., Fitriani, D., Tamuntuan, G., Agustine, E. 2013. Rock Magnetic Methods in Soil and Environmental Studies: Fundamentals and Case Studies. Procedia Earth and Planetary Science, 6, 8-13.

Bilinski, S.F., Bilinski, H., Tibljas, D., Tomasic, N., Maldini, K., Scholger,R., 2014, Initial Magnetic Susceptibility Measurement in Sediments of Croatian and Slovenian Rivers, New Trend on Paleo, Rock and Environmental Magnetism.

Dearing, J. 1996. Frequency-dependent Susceptibility Measurements of Environmental Materials. Geophys. J. Int., 124, 228-240.

Dearing, J. 1999. Environmental Magnetic Susceptibility: Using the Bartington MS2 System. British Library Cataloguing in Publication Data.

Dlouha, S., Petrovsky, E., Kapicka, A., Boruvka, L., Ash, C., Drabek, O. 2013. Investigated of Polluted Alluvial Soils by Magnetic Susceptibility Methods. A case Study of Litavka River. Soil \& Water Res. 8 (4): 151-157. 
Fahlepy, M. R., Tiwow, V. A., and Subaer. 2018. Characterization of Magnetite $\left(\mathrm{Fe}_{3} \mathrm{O}_{4}\right)$ Minerals from the Natural Iron Sand of Bonto Kanang Village Takalar for ink Powder (Toner) Application. Journal of Physics: Conference Series, 997, 012036.

Findorak, R., Frochlichova, M., and Legemza, J. 2014. Potential of Ilmenite Sand Application in the Iron Ore Materials Agglomeration. Metalurgija, 53, 9-12.

Jahidin. 2012. Analisis Suseptibilitas Magnetik Pasir Besi Desa Laea Kabupaten Buton Utara Sulawesi Tenggara. Jurnal Aplikasi Fisika, 8 (1), 20-24.

Kanu, M.O., Meludu,O.C., and Oniku, S.A, 2013, A Preliminary Assesment of Soil Pollutionin Some Parts of Jalingo, Metropilis, Nigeria Using Magnetic Susceptibility Method. Jordan Journal of Earth and Environmental Sciences, 5 (2); 53-61.

Kirana, K. H., Fitriani, D., Supriyana, E., Agustine, E. 2014. Sifat Magnetik Sedimen Sungai sebagai Indikator Pencemaran (Studi Kasus: Sungai Citarum Kabupaten Karawang). Spektra: Jurnal Fisika dan Aplikasinya, 15: 99-101.

Mufti, N., Atma, T., Fuad, A., Sutadji, E. 2014. Synthesis and Characterization of Black, Red and Yellow Nanoparticles Pigments from the Iron Sand. The 3rd International Conference on Theoretical and Applied Physics 2013 (ICTAP 2013) AIP Conference Proceedings, 1617, (165-169). New York: AIP Publishing.

Nugraha, P.A., Sari, S. P., Hidayati, W. N., Dewi, C. R., Kusuma, D. Y. 2016. The Origin and Composition of Iron Sand Deposit in the Southern Coast of Yogyakarta. The 2016 Conference on Fundamental and Applied Science for Advanced Technology (ConFAST 2016) AIP Conference Proceedings, 1746, (020028). New York: AIP Publishing.

Nurbaiti, U., 2011, Magnetic Properties of Suspended of Polluted Heavy Metal Sediment from Semarang River. Jurnal Pendidikan Fisika Indonesia, 2011(7): 134-137.

Rahmadhani, W. F., Rifai, H., dan Mufit, F. 2013. Penentuan Jenis Mineral Magnetik Guano dari Gua Solek dan Gua Rantai Kecamatan Lareh Sago Halaban Kabupaten Lima Puluh Kota Menggunakan Metode Isothermal Remanent Magnetization (IRM). Pillar of Physics, $2: 25-32$.

Sari, N., Rifai, H., dan Mufit, F. 2013. Penentuan Ukuran Bulir dan Jenis Domain Magnetik Guano dari Gua Rantai dan Gua Solek di Kecamatan Lareh Sago Halaban Kabupaten 50 Kota dengan Metode Anhysteretic Remanent Magnetization (ARM). Pillar of Physics, 2 : 18-24.

Setiadi, E. A., Sebayang, P., Ginting, M., Sari, A. Y., Kurniawan, C., Saragih, C. S., Simamora, P. 2016. The Synthesization of $\mathrm{Fe}_{3} \mathrm{O}_{4}$ Magnetic Nanoparticles Based on Natural Iron Sand by Co-Precipitation Method for the Used of the Adsorption of $\mathrm{Cu}$ and Pb Ions. J. Phys.: Conf. Ser., 776, 012020.

Sunaryono, Taufiq, A., Mashuri, Pratapa, S., Zainuri, M., Triwikantoro, Darminto. 2015. Various Magnetic Properties of Magnetite Nanoparticles Synthesized from IronSands by Coprecipitation Method at Room Temperature. Materials Science Forum, 827, 229-234.

Tamuntuan, G., Bijaksana, S., Gaffar, E., Russell, J., Safiuddin, L.O., Huliselan, E. 2010. The Magnetic Properties of Indonesian Lake Sediment: A Case Study of a Tectonic 
Lake in South Sulawesi and Maar Lakes in East Java. ITB Journal of Science, 42A (1), 31-48.

Tamuntuan, G., Tongkukut, S., dan Pasau, G. 2017. Analisis Suseptibilitas dan Histeresis Magnetik pada Endapan Pasir Besi di Sulawesi Utara. Jurnal MIPA Unsrat, 6 (2), 105-108.

Tiwow, V. A., Arsyad, M., Palloan, P., and Rampe, M. J. 2017. Analysis of Mineral Content of Iron Sand Deposit in Bontokanang Village and Tanjung Bayang Beach, South Sulawesi, Indonesia. Journal of Physics: Conference Series 997: 012010.

Zulkifli, M. D. 2002. Inventarisasi dan Evaluasi Mineral Logam di Kabupaten Takalar dan Kabupaten Gowa Provinsi Sulawesi Selatan. Kolokium Direktorat Inventarisasi Sumber Daya Mineral. 